\title{
Kajian Literatur Pengolahan Lindi Tempat Pemrosesan Akhir Sampah dengan Teknik Lahan Basah menggunakan Tumbuhan Air
}

\author{
Chusna Fajariyah dan Sarwoko Mangkoedihardjo \\ Departemen Teknik Lingkungan, Fakultas Teknik Sipil dan Perencanaan, Institut Teknologi Sepuluh Nopember (ITS) \\ e-mail: sarwoko@enviro.its.ac.id
}

\begin{abstract}
Abstrak-Lindi yang dihasilkan akibat dari proses dekomposisi sampah dapat mencemari air permukaan dan air tanah. Pemanfaatan lahan basah dengan tumbuhan air merupakan salah satu alternatif pengolahan lindi sebagai pengolahan lanjutan dari proses pengolahan primer, sekunder atau tersier. Tumbuhan air memegang peranan penting dalam proses perbaikan kualitas air limbah, terutama diaplikasikan dalam pengolahan lanjutan lindi. Pengolahan lindi dengan tumbuhan air efektif pada tumbuhan dengan akar panjang dan serabut. Tumbuhan dengan nilai TF dan BCF >1 menunjukkan tumbuhan bersifat hiperakumulator terhadap logam berat. Didapatkan 21 jenis tumbuhan air efektif terhadap pengolalahan lindi dengan tingkat konsentrasi yang dapat diterima adalah nitrogen $(112-610 \mathrm{mg} / \mathrm{L})$, fosfor $(30-75$ $\mathrm{mg} / \mathrm{L}), \mathrm{BOD}_{5}(514-686 \mathrm{mg} / \mathrm{L})$, COD $(923,4-1279 \mathrm{mg} / \mathrm{L})$, warna (1817-3360 Pt-Co), dan salinitas (3000-8000 mg/L).
\end{abstract}

Kata Kunci-Lahan Basah, Pengolahan Indi, Tumbuhan Air.

\section{LATAR BELAKANG}

$\mathrm{J}_{\mathrm{tin}}^{\mathrm{t}}$ UMLAH sampah di TPA yang sangat besar menyebabkan tingginya proses dekomposisi sampah secara alamiah yang mengubah sampah menjadi pupuk organik akibat perkolasi air hujan [1], proses biokimia sampah, dan kadar air sampah [2], sehingga melarutkan logam berat dengan hasil samping berupa lindi [3]. Kegagalan yang sering terjadi dalam pengolahan lindi disebabkan tingginya kandungan bahan organik dan anorganik [4], serta upaya pengolahan lindi masih bersifat konvensional, yakni hanya berupa bak-bak pengendapan tanpa pengolahan lanjutan [3]. Salah satu alternatif pengolahan lanjutan adalah pemanfaatan lahan basah (constructed wetland) sebagai pengolahan lanjutan atau polishing treatment limbah dari proses pengolahan sekunder atau tersier [12][21]. Constructed wetland terbukti efisien dalam mengurangi konstituen yang tidak diinginkan seperti $\mathrm{BOD}, \mathrm{COD}, \mathrm{NH}_{3}-\mathrm{N}, \mathrm{PO}_{4}-\mathrm{P}$, dan logam berat dari lindi [5].

Tumbuhan air dalam constructed wetland memegang peranan penting dalam proses pemulihan kualitas air limbah secara alamiah (self purification) [6]. Jenis tumbuhan air yang terbukti memiliki kemampuan dalam mengolah lindi adalah Phragmites mauritianus, Typha latifolia, Nymphaea spontanea, Cyperus papyrus, Typha angustifola, Limnocharis flava, Eichhornia crassipes, Pistia stratiotes, Cyperus haspan [7], Scirpus sumatrensis, Scirpus mucronatus [8], Phragmites australis, dan Glyceria maxima [9].

Berdasarkan fakta tersebut, maka perlu dilakukan kajian literatur terhadap kemampuan tumbuhan air dalam menurunkan pencemar lindi dengan constructed wetland, dan kemungkinan hasil studi untuk dapat diaplikasikan.

\section{A. Pengumpulan Literatur}

\section{METODE STUDI}

Sumber literatur yang digunakan adalah jurnal internasional, jurnal Indonesia, peraturan yang berlaku, tugas akhir, tesis, disertasi, dan text book yang berhubungan dengan topik yang dibahas. Beberapa kata kunci pencarian jurnal adalah constructed wetland systems, landfill leachate treatment, nutrien removal, heavy metal removal, organic removal, color removal, tropical region, horizontal subsurface flow, vertical subsurface flow, surface flow, plant harvesting, influence of plants, dan effect of salinity.

\section{B. Kajian Literatur}

Kajian literatur dilakukan dengan melakukan kajian berdasarkan perbandingan dari studi kasus (TPA Benowo) dengan data literatur yang telah dikumpulkan. Hasil kajian literatur dikelompokkan menjadi: karakteristik lindi, constructed wetland, penurunan pencemar organik, penurunan pencemar anorganik, plant harvesting, dan studi kasus pengaplikasian constructed wetland dengan tumbuhan air. Dari hasil kajian literatur akan diperoleh jenis tumbuhan air yang dapat diaplikasikan di TPA Benowo.

\section{KARAKTERISTIK LINDI}

\section{A. Karakteristik Lindi}

Lindi merupakan cairan dengan bau tidak sedap dan warna gelap yang umumnya mengandung bahan organik dan anorganik tinggi [10]. Karakteristik lindi dipengaruhi oleh umur landfill [11], curah hujan dan tingkat perkolasi air yang masuk ke dalam landfill, kuantitas sampah, jenis dan komposisi sampah, tingkat stabilisasi landfill [12], kelembaban landfill, posisi dan waktu pengambilan sampel [13], dan tahapan proses degradasi didalam landfill yang terdiri dari fase awal atau fase aerobik-transisi (0-5 tahun), fase pembentukan asam (5-10 tahun), fase fermentasi metan (10-20 tahun), dan fase maturasi akhir (>20 tahun) [4][12]. Karakteristik lindi dapat dilihat pada Tabel 1 [14].

Tabel 1.

Karakteristi lindi berdasarkan umur TPA 


\begin{tabular}{cccc}
\hline \hline Parameter & $\begin{array}{c}<1 \\
\text { tahun }\end{array}$ & $1-5$ tahun & $>5$ tahun \\
\hline $\mathrm{pH}$ & $<6,5$ & $6,5-7,5$ & $>7,5$ \\
$\mathrm{COD}(\mathrm{mg} / \mathrm{L})$ & $>15000$ & $3000-15000$ & $<3000$ \\
$\mathrm{BOD}_{5} / \mathrm{COD}$ & $0,5-1,0$ & $0,1-0,5$ & $<0,1$ \\
$\mathrm{NH}_{3}-\mathrm{N}(\mathrm{mg} / \mathrm{L})$ & $<400$ & 400 & $>400$ \\
$\mathrm{Logam}$ berat & $>2$ & $<2$ & $<2$ \\
$(\mathrm{mg} / \mathrm{L})$ & & & $\mathrm{HA}+\mathrm{FA}$ \\
$\begin{array}{c}\text { Senyawa } \\
\text { organik }\end{array}$ & $80 \% \mathrm{VFA}$ & $(5-30) \%$ & \\
\hline \hline
\end{tabular}

\section{CONSTRUCTED WETLAND}

\section{A. Constructed Wetland}

Constructed wetland merupakan sistem pengolahan terencana atau terkontrol yang didesain dan dibangun menggunakan proses alami yang melibatkan fungsi vegetasi, media, dan mikroorganisme untuk memanfaatkan banyak proses yang terjadi pada wetland dalam pengolahan air limbah [15]. Proses removal polutan pada sistem wetland adalah sebagai berikut (Tabel 2) [16].

Tabel 2.

Proses removal polutan pada sistem wetland

\begin{tabular}{cc}
\hline \hline Polutan & Proses \\
\hline Material organik & Degradasi secara biologis, sedimentasi, \\
serapan mikroba \\
Adsorpsi, penguapan \\
Kontaminan organik & Sedimentasi, filtrasi \\
SS & Sedimentasi, nitrifikasi-denitrifikasi, \\
Nitrogen & serapan tumbuhan dan mikroba \\
Fosfor & Sedimentasi, filtrasi, adsorpsi, serapan \\
& tumbuhan dan mikroba \\
Bakteri patogen & Kematian secara alami, sedimentasi, \\
& filtrasi, UV degradasi, adsorpsi \\
Logam berat & Sedimentasi, adsorpsi, serapan tumbuhan \\
\hline \hline
\end{tabular}

Tumbuhan air dalam wetland dibagi menjadi empat kelompok (Gambar 1), yakni emergent plant, submerged plant, floating leaved plant, dan floating plant [17].

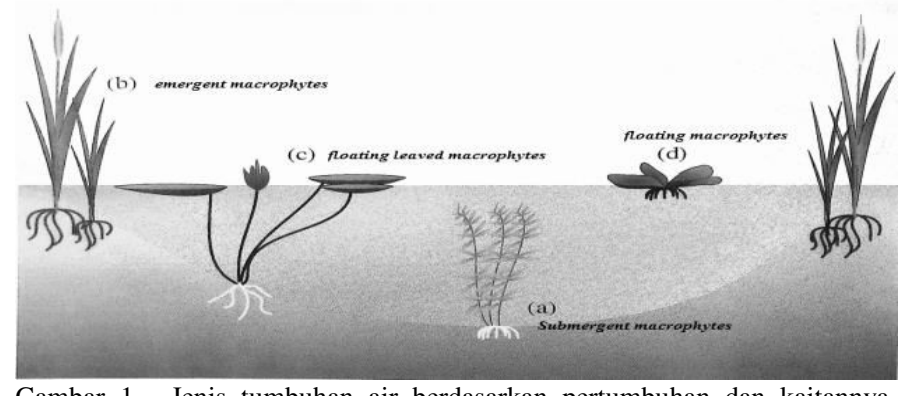

Gambar 1. Jenis tumbuhan air berdasarkan pertumbuhan dan kaitannya dengan permukaan air.

Berdasarkan arah aliran, terdapat dua jenis constructed wetland yakni free water surface (FWS) dan subsurface flow (SSF). Sistem SSF CWs terbagi menjadi horizontal subsurface flow (HSSF) dan vertical subsurface flow (VSSF) [47].

\section{PENURUNAN KANDUNGAN ANORGANIK}

\section{A. Nitrogen dan Fosfor}

Penurunan utama nitrogen adalah melalui proses nitrifikasi- denitrifikasi [18]. Proses nitrifikasi yang lebih panjang pada kondisi aerobik berpengaruh terhadap tingkat pertumbuhan tumbuhan. Kondisi ini menunjukkan bahwa denitrifikasi pada kondisi anaerobik dimungkinkan belum terjadi. Jika dilihat dari keefektifan tumbuhan, kondisi ini menguntungkan dibandingkan kondisi anaerobik.

Penurunan $\mathrm{NH}_{3}-\mathrm{N}$ dan $\mathrm{NH}_{4}-\mathrm{N}$ dipengaruhi oleh proses nitrifikasi, serapan tumbuhan, aktivitas mikroba aerob, dan media yang digunakan dapat mendukung penurunan terjadi lebih baik. Sistem VSSF CWs menunjukkan penurunan nitrogen lebih besar dibandingkan HSSF CWs dikarenakan suplai oksigen yang lebih mendukung pada sistem vertikal. Hal ini ditunjukkan dari hasil penelitian [19][20] dengan tumbuhan kangkung (Ipomoeae aquatic) dan Typha latifolia dengan penurunan mencapai $70 \%$ oleh Typha latifolia dari konsentrasi $122 \pm 26,7 \mathrm{mg} / \mathrm{L}$ dan $97,77 \%$ oleh Ipomoea aquatic dari konsentrasi $610 \pm 365,43 \mathrm{mg} / \mathrm{L}$. Kemampuan uptake tumbuhan salah satunya dipengaruhi oleh karakteristik akar yang lebih serabut dan panjang, yang dapat memberikan ruang lebih luas bagi mikroorganisme di akar, sehingga suplai oksigen tinggi dan meningkatkan aktivitas mikroba pada proses nitrifikasi. Seperti pada penelitian [8] Limnocharis flava dengan akar lebih serabut dan panjang memberikan penurunan lebih besar dibandingkan Scirpus atrovirens.

Sehingga tumbuhan air yang berpotensi terhadap penurunan nitrogen adalah tumbuhan genjer (Limnocharis flava), Ipomoeae aquatica, dan Scirpus validus. Typha latifolia dan Phragmites australis memiliki kemampuan penurunan nitrogen lebih tinggi apabila kedua tumbuhan tersebut dilakukan pada sistem single plant. Mixed plant bersifat antagonistik antara Typha latifolia dengan Scirpus validus, Carex lacustris, dan Phalaris arundinacea [21]. Sedangkan Phragmites australis dengan Typha orientalis [22].

Penurunan fosfor dan fosfat $\left(\mathrm{PO}_{4}-\mathrm{P}\right)$ terjadi melalui proses sedimentasi, adsorpsi, dan aktivitas mikroba, dan serapan tumbuhan [20]. Penelitian [20][23] penurunan fosfor sangat dibatasi oleh jenis media dan ukuran media yang digunakan. Media dengan kandungan $\mathrm{Fe}$, $\mathrm{Al}$, dan $\mathrm{Ca}$ dalam jumlah besar dapat memfasilitasi proses presipitasi atau adsorpsi $\mathrm{P}$. Penurunan $\mathrm{PO}_{4}-\mathrm{P}$ oleh Typha latifolia pada sistem VSSF CWs dengan kombinasi media zeolit, pasir, dan kerikil memberikan penurunan hingga $83 \%$ dari konsentrasi $75 \mathrm{mg} / \mathrm{L}$ [54]. Penelitian [36] dengan Typha latifolia memberikan penurunan fosfor hingga 90\% pada sistem HSSF CWs dengan kombinasi media pasir pada konsentrasi $30-50 \mathrm{mg} / \mathrm{L}$. Dari keduanya menunjukkan bahwa penurunan fosfor dipengaruhi oleh media, waktu kontak, dan adanya tumbuhan (penurunan fosfor lebih rendah pada sistem tanpa tumbuhan) [8].

\section{B. Logam Berat}

Penyerapan logam berat dalam constructed wetland dapat terjadi dari proses adsorpsi (media) maupun serapan tumbuhan [24] melalui penyerapan, pertukaran kation, filtrasi, dan perubahan kimia melalui akar [25][26].

i) Akumulasi di Jaringan Akar, Batang, dan Daun

Gambar 3 [5] menunjukkan penurunan $\mathrm{Fe}$ dan Mn paling 
banyak diakumulasi di bagian akar. Hasil ini koheren dengan [24] Cyperus alternifolius terhadap akumulasi $\mathrm{Fe}, \mathrm{Cu}$, dan $\mathrm{Zn}$, [27] Canna indica, Cyperus alternifolius, dan Typha angustifolia terhadap akumulasi $\mathrm{Zn}, \mathrm{Ni}, \mathrm{Cu}, \mathrm{Cr}, \mathrm{Co}$, dan [28] Limnocharis flava terhadap akumulasi $\mathrm{Fe}, \mathrm{Mn}$, dan fosfat. Hal ini dikarenakan akar berperan penting terhadap kemampuan rizofiltrasi kontaminan dibandingkan batang dan daun. Selain itu akar yang lebih panjang dan serabut lebih mampu untuk menciptakan zona aerasi untuk menyerap kontaminan.

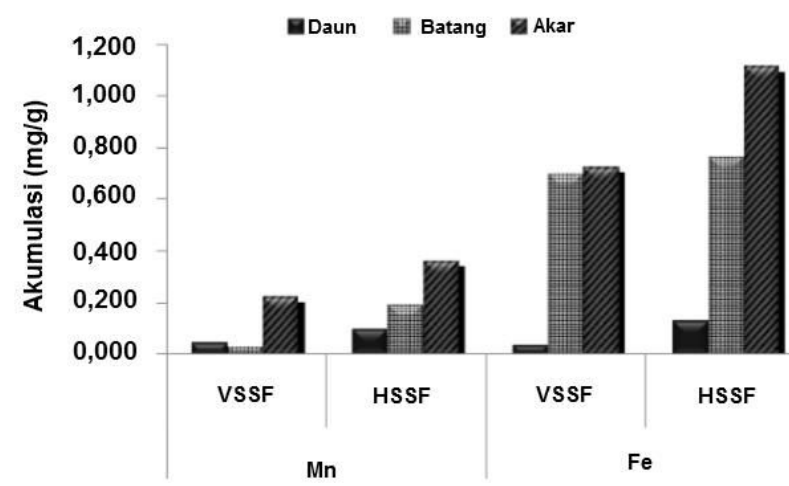

Gambar 3. Akumulasi logam berat dalam jaringan Limnocharis flava setelah 45 hari.

HSSF CWs memiliki penurunan yang lebih besar dibandingkan sistem VSSF CWs karena terkait HRT yang terjadi lebih lama atau lebih panjang pada sistem ini. Selain itu penurunan logam berat pada sistem dengan tumbuhan memberikan penurunan yang lebih besar dibandingkan sistem tanpa tumbuhan.

ii) $\mathrm{TF}$ dan $\mathrm{BCF}$

Nilai Translocation Factor (TF) digunakan untuk memperkirakan kemampuan kapasitas logam berat yang ditranslokasikan dari akar menuju tunas [26][28]. Nilai TF dapat diperkirakan dengan persamaan sebagai berikut:

$$
T F=\frac{C_{\text {tunas }}}{C_{\text {akar }}}
$$

Nilai TF>1 menunjukkan besarnya kemampuan serapan dan translokasi logam berat dari akar menuju tunas, tumbuhan bersifat hiperakumulator terhadap logam berat, dan baik dalam fitoekstraksi atau fitoakumulasi [26]. Tumbuhan dengan nilai $\mathrm{TF}>1$ adalah Juncus effusus (Cd, Ni, $\mathrm{Pb}, \mathrm{Mn}$, dan $\mathrm{Zn}$ ) [29], Typha domingensis ( $\mathrm{Pb}, \mathrm{Ni}, \mathrm{Cd})$ [31], dan Eichhornia crassipes (logam berat $\mathrm{Ni}, \mathrm{Zn}, \mathrm{Cr}$ ) [30].

Bioconcentration Factor (BCF) menunjukkan kemampuan biokonsentrasi dari tumbuhan terhadap logam berat di dalam jaringannya. BCF juga menjadi indikator terhadap kemampuan akumulasi oleh tumbuhan. Nilai BCF dapat diperkirakan dengan persamaan sebagai berikut:

$$
B C F=\frac{C_{\text {jaringan }}}{C_{\text {lindi }}}
$$

Dimana $\mathrm{C}_{\text {jaringan }}$ merupakan konsentrasi di seluruh jaringan tumbuhan dinyatakan dalam $(\mathrm{mg} / \mathrm{kg})$, dan $\mathrm{C}_{\text {lindi }}$ merupakan konsentrasi di dalam lindi dinyatakan dalam $(\mathrm{mg} / \mathrm{L})$ [31]. Tumbuhan dengan nilai $\mathrm{BCF}>1$ menunjukkan besarnya kemampuan serapan logam berat dan pertumbuhan yang lebih tinggi. Tumbuhan dengan nilai $\mathrm{BCF}>1$ adalah Eichhornia crassipes terhadap logam berat $\mathrm{Ni}, \mathrm{Cd}, \mathrm{Pb}, \mathrm{Cu}$, dan $\mathrm{Cr}$ (BCF 1,42) [31]. Penelitian dari [32] menunjukkan 19 jenis tumbuhan air dengan nilai $\mathrm{BCF}>1$ yakni Alternanthera philoxeroides, Zizania latifolia, Echinochloa crus-galli, Polygonum hydropiper (terhadap logam berat $\mathrm{Cd}, \mathrm{Pb}, \mathrm{Zn}$ ), Monochoria vaginalis $(\mathrm{Cd}$ dan $\mathrm{Pb})$, Isachne globosa $(\mathrm{Cd}$ dan $\mathrm{Zn})$, Digitaria sanguinalis, Fimbristylis miliacea (Zn).

iii) Hubungan TF dan $\mathrm{BCF}$

Fitoakumulasi oleh tumbuhan ditentukan dengan menghitung nilai $\mathrm{BCF}$ dan $\mathrm{TF}$ untuk dapat membedakan mekanisme akumulasi yang terjadi, yakni [33]:

Nilai BCF $>1$ dan TF $<1$ (mekanisme fitostabilisasi)

Nilai $\mathrm{BCF}<1$ dan TF $>1$ (mekanisme fitoekstraksi)

Tumbuhan dibagi dalam 3 kategori terkait nilai BCF dan TF, yakni [45]:

$\mathrm{BCF}>1$

(tumbuhan akumulator)

$\mathrm{BCF}<1$

$\mathrm{BCF}$ mendekati $1 \quad$ (indikator)

$\mathrm{TF}>1 \quad$ (mekanisme fitoekstraksi)

$\mathrm{TF}<1 \quad$ (mekanisme fitostabilisai)

Penelitian dari [29][28], menunjukkan variasi nilai TF dan BCF dari tumbuhan Juncus effusus, Phragmites australis, Canna indica, Typha angustifolia, dan Cyperus alternifolius terhadap logam berat $\mathrm{Cd}, \mathrm{Cr}, \mathrm{Fe}, \mathrm{Mn}, \mathrm{Ni}, \mathrm{Pb}, \mathrm{Zn}, \mathrm{Cu}$, dan $\mathrm{Co}$. Juncus effusus memiliki kemampuan translokasi lebih besar dibandingkan Phragmites australis dengan rata-rata nilai $\mathrm{TF}>1$ namun kemampuan akumulasi (BCF) $<1$. Sedangkan Phragmites australis nilai TF $>1$ hanya pada logam berat Mn dan $\mathrm{Pb}$. Canna indica, Typha angustifolia, dan Cyperus alternifolius dari penelitian [28] menunjukkan nilai $\mathrm{TF}<1$ terhadap seluruh logam berat namun memberikan nilai $\mathrm{BCF}>1$. Dari penelitian diatas menunjukkan bahwa peningkatan nilai TF tidak berhubungan dengan peningkatan nilai BCF.

\section{PENURUNAN KANDUNGAN ORGANIK}

\section{A. BOD dan $C O D$}

Kandungan organik lindi umumnya diukur sebagai BOD dan COD. Penurunan BOD dan COD pada sistem SSF CWs dengan Cyperus alternifolius mencapai 64\% dari konsentrasi masing-masing $514 \mathrm{mg} / \mathrm{L}$ dan $1279 \mathrm{mg} / \mathrm{L}$ pada sistem HSSF CWs [34]. Penelitian dari [7] juga memberikan hasil yang koheren dimana penurunan oleh Cyperus haspan paling besar pada sistem HSSF CWs. Cyperus haspan mampu menurunankan BOD hingga 60,8-78,7\% dan COD 59,7-98,8\% dari konsentrasi BOD $686 \mathrm{mg} / \mathrm{L}$ dan COD 923,4 mg/L selama 21 hari. Dari keduanya menunjukkan bahwa HSSF CWs lebih baik terhadap penurunan BOD dan COD dibandingkan sistem VSSF CWs dikarenakan waktu kontak yang lebih lama atau lebih panjang antara mikroba dengan kontaminan. 
Konsentrasi awal BOD dan COD menentukan tingkat biodegradabilitas indi. Rasio BOD/COD dibagi menjadi 3 zona yakni zona toksik (BOD/COD $<0,1)$, zona biodegradable (BOD/COD 0,1-1,0), dan zona stabil (BOD/COD 0,1 namun kandungan organik aman untuk lingkungan) [35]. Pengaruh tingkat biodegradabilitas lindi terhadap kemampuan serapan tumbuhan ditunjukkan dari penelitian [36] dengan Typha angustifolia, efisiensi pengolahan menurun sekitar $27 \%$ pada lindi tua. Hasil yang koheren juga ditunjukkan dari penelitian dan [20] Typha latifolia pada sistem HSSF CWs yakni sekitar $35,7 \%$ dari konsentrasi COD 211,8 mg/L. Hal ini disebabkan adanya kandungan organik yang tidak terurai pada lindi stabil menyebabkan penurunan rasio $\mathrm{BOD} / \mathrm{COD}(<0,1)$ [37] sehingga lindi bermutu toksik dengan tingkat biodegradabilitas rendah [38] serta mikroba dari landfill tua sudah tidak aktif. Lindi dengan BOD/COD $>0,1$, penurunan BOD dan COD oleh Typha angustifolia mencapai $91 \%$ dan $81,6 \%$ pada HRT 8 hari dari konsentrasi awal BOD $130 \mathrm{mg} / \mathrm{L}$ dan COD $385 \mathrm{mg} / \mathrm{L}$ [39]. Penurunan mencapai $94 \%$ pada konsentrasi BOD 141,21 $\mathrm{mg} / \mathrm{L}$ dan COD 661,65 mg/L oleh [40].

Tumbuhan memberikan efek terhadap jumlah oksigen yang tersedia dalam media, sehingga dapat mendukung pertumbuhan mikroba dan porositas media lebih besar karena pengaruh akar tumbuhan, serta dapat menaikkan biodegradabilitas lindi. Pengaruh akar tumbuhan ditunjukkan oleh [16], penurunan oleh Ericaulon sexangulora dengan akar lebih panjang dan serabut lebih besar dibandingkan Scirpus globulosus. Penurunan mencapai $>85 \%$ setelah 18 hari pada konsentrasi BOD $950 \mathrm{mg} / \mathrm{L}$ dan COD $350 \mathrm{mg} / \mathrm{L}$. Dari beberapa penelitian diatas, didapatkan Cyperus haspan, Cyperus alternifolius, Typha angustifolia, dan Ericaulon sexangulora dapat dijadikan rekomendasi terhadap penuruan BOD dan COD pada konsentrasi BOD 514-686 mg/L dan COD 923,4-1279 mg/L.

\section{B. Warna}

Warna lindi menggambarkan besarnya konsentrasi bahan organik pada lindi. Semakin pekat warna lindi maka semakin tinggi kandungan bahan organik didalamnya (diukur sebagai $\mathrm{COD})$ yang menandakan rendahnya rasio $\mathrm{BOD}_{5} / \mathrm{COD}$, kekeruhan, dan suspended solid [2][29]. Warna lindi juga disebabkan oleh oksidasi $\mathrm{Fe}$ dari $\mathrm{Fe}^{2+}$ menjadi $\mathrm{Fe}^{3+}$ dan pembentukan koloid besi hidroksida $\left(\mathrm{Fe}\left(\mathrm{OH}_{3}\right)\right)$ dan kompleks dengan zat fulvat/humat (lindi berwarn kemerahan) [41]. Intensitas warna lindi pada landfill muda adalah pada rentang 2430-8180 Pt-Co [42]. Sedangkan pada landfill tua intensitas warna meningkat yakni 7200-9250 Pt-Co [43][44].

Hasil penelitian [26][7] menunjukkan bahwa penurunan warna berbanding lurus dengan meningkatnya waktu kontak. Waktu kontak optimum terhadap penurunan warna oleh Typha domingensis pada sistem VSSF CWs terjadi pada waktu kontak 42 jam dengan penurunan mencapai $68,92 \%$ pada intensitas warna 1817 Pt-Co. Cyperus haspan pada sistem VSSF CWs penurunan selama 21 hari mencapai $86,6 \%$ pada konsentrasi 3360 Pt-Co. Sedangkan penelitian dari [39], menunjukkan penurunan optimum Typha angustifolia hanya mencapai $45 \%$ pada intensitas warna yang lebih rendah (137 Pt-Co). Sehingga Typha domingensis dan Cyperus haspan dapat dijadikan rekomendasi terhadap penurunan warna dengan constructed wetland.

\section{PLANT HARVESTING}

Plant harvesting merupakan salah satu strategi untuk meningkatkan pertumbuhan tumbuhan dan kinerja constructed wetland yang dapat dilakukan tahunan (annual harvesting) dan berganda (multiple harvesting). Harvesting dapat dilakukan ketika tumbuhan telah berada pada siklus akhir tumbuhnya. Pengulangan pemanenan terbukti dapat meningkatkan jumlah nutrien yang dapat diturunkan [45]. Tumbuhan yang memungkinkan dilakukan multiple harvesting adalah Phalaris arundinacea [45], Scirpus grossus dan Typha angustifolia (Gambar1) [46]. Scirpus grossus membutuhkan waktu lebih cepat untuk mencapai produktivitas maksimal yakni sekitar 5 bulan pada pertumbuhan awal, sedangkan Typha angustifolia membutuhkan sekitar 8 bulan.

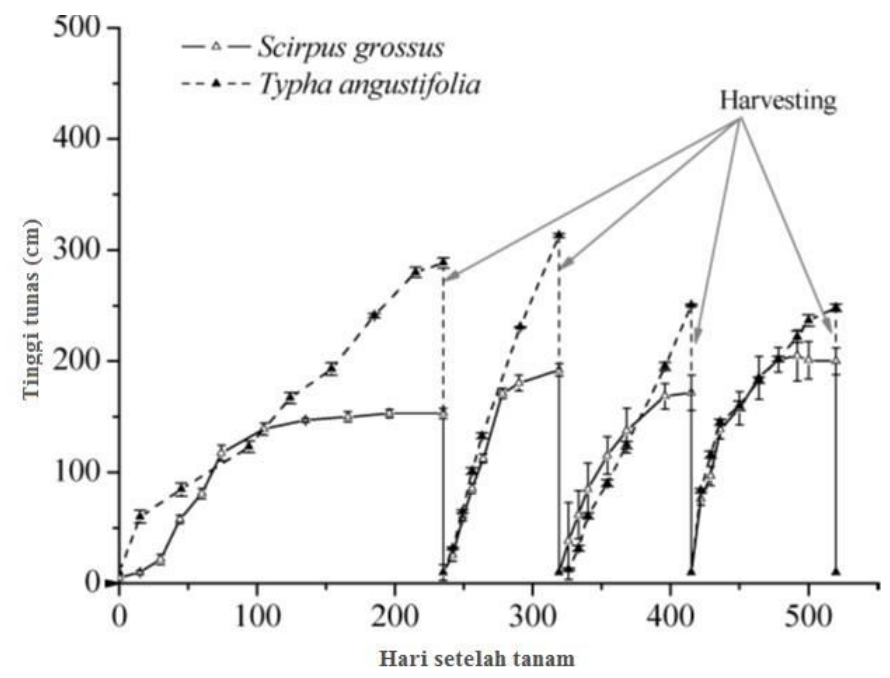

Gambar 4. Perubahan tinggi tunas Scirpus grossus dan Typha angustifolia setelah 4 kali harvesting.

Keberhasilan awal pertumbuhan merupakan faktor penting terhadap keberhasilan pertumbuhan selanjutnya [46]. Setelah dilakukan pemanenan, tumbuhan menyimpan energi di bagian akar untuk regenerasi tunas [47]. Spesies tumbuhan yang baik untuk dilakukan harvesting sebaiknya adalah tumbuhan yang memiliki pertumbuhan yang cepat [48]. Hal ini menunjukkan tumbuhan memiliki kemampuan yang lebih cepat untuk mencapai produktivitas maksimal dalam penyerapan polutan. Pemilihan metode harvesting dapat dipertimbangkan berdasarkan kemudahan operasi, peralatan, SDM, biaya, dan manfaat dari hasil harvesting.

\section{STUDI KASUS}

TPA Benowo merupakan TPA yang melayani pembuangan sampah Kota Surabaya dan telah beroperasi dari tahun 2001. Luas lahan TPA sekitar 37,4 Ha dengan sampah yang diterima 
sekitar 6064 ton/hari [49][50]. Karakteristik lindi TPA Benowo mengandung khlorida $\left(\mathrm{Cl}^{-}\right)$tinggi yakni $10300 \mathrm{mg} / \mathrm{L}$ diakibatkan lokasi TPA dekat tambak garam yang sehingga air tanah mengandung garam tinggi akibat dari infiltrasi air laut dan terakumulasi ke dalam lindi. Konsentrasi salinitas salah satunya dipengaruhi kandungan $\mathrm{Cl}^{-}$. Lindi dengan salinitas tinggi menyebabkan tumbuhan sebagai pengolah lindi secara biologis tidak dapat menguraikan bahan organik sehingga mengakibatkan penurunan efisiensi pengolahan [51] dan sifat toksik tumbuhan [31]. Dari beberapa hasil penelitian, tumbuhan yang mampu bertahan pada kondisi salin adalah Enceng gondok (Eichhornia crassipes) mampu bertahan pada konsentrasi salinitas 560-3000 mg/L [31][52]. Rumput bebek (Lemna minor) pada konsentrasi salinitas 3000-7000 mg/L, dan Lembang (Typha domingensis) pada konsentrasi salinitas hingga $8000 \mathrm{mg} / \mathrm{L}$ [53]. Sehingga spesies tersebut dapat dijadikan rekomendasi di TPA Benowo sebagai pengolahan lanjutan lindi dengan constructed wetland. Selain karena kemampuannya pada kondisi salin, tumbuhan tersebut tersebar di Indonesia, tingkat pertumbuhan cepat, dan kemampuan terhadap penurunan parameter lain. Typha angustifolia memiliki kemampuan terhadap penurunan BOD, COD, N, dan P mencapai >90\% [39][40]. Eichhornia crassipes terhadap penurunan $\mathrm{Ni}, \mathrm{Zn}, \mathrm{Cr}$, dan $\mathrm{Cd}$, TSS, TDS, dan kandungan organik [51]. Lemna minor terhadap penurunan $\mathrm{Mn}, \mathrm{Pb}, \mathrm{Ni}$, $\mathrm{Cu}, \mathrm{Cr}$, dan Cd mencapai $>50 \%$ [32].

\section{KESIMPULAN/RINGKASAN}

Pengolahan lindi dengan tumbuhan air efektif pada tumbuhan dengan akar panjang dan serabut. Limnocharis flava, Ipomoeae aquatica, dan Scirpus validus efektif terhadap penurunan nitrogen mencapai $>90 \%$ pada konsentrasi $112-610$ mg/L. Typha latifolia efektif terhadap penurunan fosfor mencapai $90 \%$ pada konsentrasi 30-75 mg/L. Cyperus haspan, Cyperus alternifolius, Eriocaulon sexangulare dan Typha angustifolia efektif terhadap penurunan BOD dan COD mencapai $>60 \%$ pada konsentrasi $\mathrm{BOD}_{5}$ 514-686 mg/L dan COD 923,4-1279 mg/L. Cyperus haspan dan Typha domingensis efektif terhadap penurunan warna lindi pada rentang 1817-3360 Pt-Co. Typha angustifolia, Eichhornia crassipes, dan Lemna minor efektif terhadap lindi dengan salinitas tinggi (salinitas yang dapat diterima masing-masing adalah $8000 \mathrm{mg} / \mathrm{L}, 3000 \mathrm{mg} / \mathrm{L}$, dan $7000 \mathrm{mg} / \mathrm{L}$ ). Tumbuhan dengan nilai $\mathrm{TF}$ dan $\mathrm{BCF}>1$ bersifat hiperakumulator terhadap logam berat. Tumbuhan dengan nilai $\mathrm{TF}>1$ adalah Eichhornia crassipes, Typha domingensis, dan Juncus effusus. Tumbuhan dengan nilai $\mathrm{BCF}>1$ adalah Alternanthera philoxeroides, Zizania latifolia, Echinochloa crus-galli, Polygonum hydropiper, Monochoria vaginalis, Isachne globosa, Digitaria sanguinalis, Fimbristylis miliacea, Eichhornia crassipes, dan Canna indica.

\section{UCAPAN TERIMA KASIH}

Penulis mengucapkan terimakasih kepada segenap pihak di
Jurusan Teknik Lingkungan FTSP ITS, atas bantuan dan dukungan dalam penyelesaian studi literatur ini.

\section{DAFTAR PUSTAKA}

[1] Al-Hamadani, Y. A.J., M. S. Yusoff, M. Umar, Bashir, and M. J.K., "Application of Psyllium Husk as Coagulant and Coagulant Aid in Semi-Aerobic Landfill Leachate Treatment," J. Hazard. Mater., vol. 190, pp. 582-587, 2011.

[2] S. Renou, J. G. Givaudan, S. Poulain, F. Dirassouyan, and P. Moulin, "Landfill Leachate Treatment: Review and Opportunity," J. Hazard. Mater., vol. 150, pp. 468-493, 2008.

[3] M. S. Anam, E. M.H., Kurniati, and B. Suharto, "Penurunan Kandungan Logam $\mathrm{Pb}$ dan $\mathrm{Cr}$ Leachate Melalui Fitoremediasi Bambu Air (Equisetum hyemale) dan Zeolit," J. Keteknikan Pertan. Trop. dan Biosist., vol. 1, pp. 43-59, 2013.

[4] S. Q. Aziz, H. A. Aziz, M. S. Yusoff, M. J. K. Bashir, and M. Umar, "Leachate Characterization in Semi Aerobic and Anaerobic Sanitary Landfill: A Comparative Study," J. Environ. Manage., vol. 91, pp. 2608-2614, 2010.

[5] A. N. Kamarudzaman, M. A. H. Zakaria, R. A. Aziz, and M. F. A. Jalil, "Study the Accumulation of Nutrients and Heavy Metals in the Plant Tissues of Limnocharis flava Planted in Both Vertical and Horizontal Subsurface Flow Constructed Wetland," IPCBEE, vol. 12, pp. 50-54, 2011.

[6] H. Suprihatin, "Penurunan Konsentrasi BOD Limbah Domestik menggunakan Sistem Wetland dengan Tanaman Hias Bintang Air (Cyperus alternifolius)," Din. Lingkung. Indones., vol. 1, pp. 8087, 2014.

[7] C. O. Akinbile, M. S. Yusoff, and A. Z. A. Zuki, "Landfill Leachate Treatment using Sub-Surface Flow Constructed Wetland by Cyperus haspan," Waste Manag., vol. 32, pp. 1387-1393, 2012.

[8] A. N. Kamarudzaman, N. S. Ismail, and R. A. Aziz, "Removal of Nutrients from Landfill Leachate Using Subsurface Flow Constructed Wetland Planted with Limnocharis flava and Scirpus atrovirens. Proceeding International," in Proceeding International Conference on Environmental and Computer Science, 2011.

[9] A. Bialowiec, L. Davies, A. Albuquerque, and P. F. Randerson, "Nitrogen Removal from Landfill Leachate in Constructed Wetlands with Reed and Willow: Redox Potential in the Root Zone," J. Environ. Manage., vol. 97, pp. 22-27, 2012.

[10] P. Yao, "Perspectives on Technology for Landfill Leachate Treatment," Arab. J. Chem., pp. 1-8, 2013.

[11] D. Kulikowska and E. Klimiuk, "The Effect of Landfill Age on Municipal Leachate Composition," Bioresour. Technol., vol. 99, pp. 5981-5985, 2008.

[12] E. M. Pajooh, D. Weichgrebe, and G. Cuff, "Municipal Landfill Leachate Characteristics and Feasibility of Retrofitting Existing Treatment Systems with Deammonification-A Full Scale Survey," J. Environ. Manage., vol. 187, pp. 354-364, 2017.

[13] E. Damanhuri, "Diktat Kuliah Perancangan Landfill," Bandung, 2012.

[14] A. A. Abbas, G. Jingsong, Z. P.L., Y. Y.P., and W. S. Alrekabi, "Review on Landfill Leachate Treatments," Am. J. Appl. Sci., vol. 6, pp. 672-684, 2009.

[15] D. Q. Zhang, K. B. S. N. Jinadasa, R. M. Gersberg, Y. Liu, and W. J. Tan, S.K., Ng, "Application of Constructed Wetlands for Wastewater Treatment in Tropical and Subtropical Regions (20002013)," J. Environ. Sci., vol. 30, pp. 30-46, 2015.

[16] Z. Ujang, E. Soejono, M. R. Salim, and R. B. Shutes, "Landfill Leachate Treatment by an Experimental Subsurface Flow Constructed Wetland in Tropical Climate Countries," Water Sci. Technol., vol. 52, no. 12, pp. 243-250, 2005.

[17] N. Tanaka and K. B. S. N. W.J. Jinadasa, Wetlands for Tropical Applications; Waswater Treatment by Constructed Wetland. London: Imperial Collage Press, 2011.

[18] C. . Lee, T. D. Fletcher, and G. Sun, "Nitrogen Removal in Constructed Wetland Systems," Eng. Life Sci., vol. 1, pp. 11-22, 2009.

[19] O. O. Aluko and M. K. . Sridhar, "Application of Constructed Wetlands to the Treatment of Leachates from a Municipal Solid 
Waste Landfill in Ibadan, Nigeria," J. Environ. Health, vol. 6, no. 10, pp. 58-62, 2005.

[20] A. Yalcuk and A. Ugurlu, "Comparison of Horizontal and Vertical Constructed Wetland System for Landfill Leachate Treatment," Bioresour. Technol., vol. 100, pp. 2521-2526, 2009.

[21] L. H. Fraser, S. M. Carty, and D. Steer, "A Test of Four Plant Species to Reduce Total Nitrogen and total Phosphorus from Soil Leachate in Subsurface Wetland Microcosms," Bioresour. Technol., vol. 94, pp. 185-192, 2004.

[22] L. Yang and K. . Tsai, "Treatment of Landfill Leachate with High Levels of Ammonia by Constructed Wetland Systems," J. Environ. Sci. Heal. Part A, vol. 46, pp. 736-741, 2011.

[23] A. M. Noor, L. C. Shiam, F. W. Hong, S. Soetardjo, and H. P. S. A. Khalil, "Application of Vegetated Constructed Wetland with Different Filter Media for Removal of Ammoniacal Nitrogen and Total Phosphorus in Landfill Leachate," Int. J. Chem. Eng. Appl., vol. 1, no. 3, pp. 270-275, 2010.

[24] A. N. Kamarudzaman, R. A. Aziz, and M. F. A. Jalil, "Removal of Heavy Metals from Landfill Leachate using Horizontal and Vertical Subsurface Flow Constructed Wetland Planted with Limnocharis flava," Int. J. Civ. Environ. Eng. IJCEE-IJENS, vol. 11, pp. 73-79, 2011.

[25] A. Mojiri, H. A. Aziz, M. A. Zahed, S. Q. Aziz, and R. B. M. Selamat, "Phytoremediation of Heavy Metals from Urban Waste Leachate by Southern Cattail (Typha domingensis)," Int. J. Sci. Res. Environ. Sci., vol. 1, no. 4, pp. 63-70, 2013.

[26] A. Mojiri, L. Ziyang, R. M. Tajuddin, H. Farraji, and N. Alifar, "Co-Treatment of Landfill Leachate and Municipal Wastewater using the ZELIAC/Zeolit Constructed Wetland System," J. Environ. Manage., vol. 166, pp. 124-130, 2016.

[27] M. A. Khapre, "Removal of Heavy Metal from Landfill Leachate using Vertical Flow Construction Wetland," IOSR J. Mech. Civ. Eng., pp. 46-51, 2015.

[28] A. K. Yadav, R. Abbassi, N. Kumar, S. Satya, T. R. Sreekrishnan, and B. K. Mishra, "The Removal of Heavy Metals in Wetland Microcosms: Effects of Bed Depth, Plant Species, and Metal Mobility," Chem. Eng. J., vol. 212, pp. 501-507, 2012.

[29] A. D. Oka, M. Fujii, Y. Soda, S. Ishigaki, T. Machimura, and M. T. Ike, "Removal of Heavy Metals from Synthetic Landfill Leachate in Lab-Scale Vertical Flow Constructed Wetlands," Sci. Total Environ., pp. 742-750, 2017.

[30] S. Verma, B. Mishra, R.Pandit, A. Chatterjee, S. S. Jadhav, P. S. Gaoture, and P. H. Sarode, "Treatment of Landfill Leachate by Phytoremediation," Int. J. Eng. Res. Gen. Sci., vol. 3, pp. 12341237,2015

[31] A. S. El-Gendy, N. Biswas, and J. K. Bewtra, "A Floating Aquatic System Employing Water Hyacinth for Municipal Landfill Leachate Treatment: Effect of Leachate Characteristics on the Plant Growth," J. Environ. Eng. Sci., vol. 4, pp. 227-240, 2005.

[32] J. Liu, Y. Dong, H. Xu, D. Wang, and J. Xu, "Accumulation of Cd, $\mathrm{Pb}$, and $\mathrm{Zn}$ by 19 Wetland Plant Species in Constructed Wetland," J. Hazardouz Mater., vol. 147, pp. 947-953, 2007.

[33] Yafyet, S. Liong, and Y. Hala, "Fitoakumulasi $\mathrm{Cr}$ dan $\mathrm{Pb}$ dalam Tumbuhan Bakau Rhizophora mucronata di Daerah Aliran Sungai Tallo Makassar," Makassar, 2016.

[34] S. Usman and I. Santosa, "Pengolahan Air Limbah Sampah (Lindi) dari Tempat Pembuangan Akhir Sampah (TPA) menggunakan Metoda Constructed Wetland," J. Kesehat., vol. 5, no. 2, pp. 98108, 2014.

[35] G. Samudro and S. Mangkoedihardjo, "Review nn BOD, COD and BOD/COD Ratio: a Triangle Zone for Toxic, Biodegradable and Stable Levels," Int. J. Acad. Res., vol. 2, no. 4, pp. 235-239, 2010.

[36] C. Chiemchaisri, W. Chiemchaisri, J. Junsod, and P. . Threedeach, S. Wicranarachchi, "No Title," Bioresour. Technol., vol. 100, pp. 3808-3814, 2009.

[37] E. Klimiuk and D. Kulikowska, "The Influence of Hydraulic Retention Time and Sludge Age on the Kinetics of Nitrogen Removal from Leachate in SBR," Polish J. Environ. Stud., vol. 1, no. 2, pp. 283-289, 2006.

[38] S. Mangkoedihardjo and G. Samudro, Fitoteknologi Terapan. Yogyakarta: Graha Ilmu, 2010.

[39] V. Sawaittayothin and C. Polprasert, "Nitrogen Mass Balance and Microbial Analysis of Constructed Wetlands Treating Municipal Landfill Leachate," Biosource Technol., vol. 98, pp. 565-570, 2007

[40] T. D. Ariny and T. Zaman, B. Istirokhatun, "Penyisihan BOD dan COD dalam Lindi pada Constructed Wetland menggunakan Typha angustifolia dengan Pengaruh Debit dan Jumlah Tumbuhan yang Berbeda (Studi Kasus: Tempat Pembuangan Sampah Kawasan Industri Terboyo, Semarang, Jawa Tengah)," J. Tek. Lingkung., vol. 3, no. 4, pp. 1-19, 2014.

[41] E. Nagarajan, R. Thirumalaisamy, S. Lakshumanan, "Impact of Leachate on Groundwater Pollution due to non-Engineered Municipal Solid Waste Landfill Sites of Erode City, Tamil Nadu, India," Iran. J. Environ. Heal. Sci. Eng., vol. 9, pp. 35-41, 2012.

[42] H. A. Aziz, S. Alias, M. N. Adlan, F. A. H. Asaari, and M. S. M. Zahari, "Colour Removal from Landfill Leachate by Coagulation and Flocculation Processes," Bioresour. Technol., vol. 98, pp. 218 $220,2007$.

[43] N. B. Azmi, M. J. K. Bashir, S. Sethupathi, L. J. We, and N. C. Aun, "Stabilized Landfill Leachate Treatment by Sugarcane Bagasse Derived Activated Carbon for Removal of Color, COD and NH3-N - Optimization of Preparation Condition by RSM," $J$. Environ. Chem. Eng., vol. 513, pp. 1-8, 2014.

[44] E. Papastavrou, C. Mantzavinos, D. Diamadopulos, "A Comparative Treatment of Stabilized Landfill Leachate: Coagulation and Activated Carbon Adsorption vs Electrochemical Oxdation," Environ. Technol., vol. 10, no. 14, pp. 1547-1553, 2009.

[45] J. Vymazal, L. KrÖpfelová, J. Švehla, and J. Štíchová, "Can Multiple Harvest of Above Ground Biomass Enhance Removal of Trace Elements in Constructed Wetlands Receiving Municipal Sewage?," Ecol. Eng., vol. 36, pp. 939-945, 2010.

[46] K. B. S. N. Jinadasa, N. Tanaka, S. Sasikala, M. I. M. Werellagama, D.R.I.B. Mowjood, and W. J. Ng, "Impact of Harvesting onCconstructed Wetlands Performance-A Comparison between Scirpus grossus and Typha angustifolia," J. Environ. Sci. Heal., vol. 43, pp. 664-671, 2008.

[47] P. K. Pal, M. Mahajan, R. Prasad, V. Pathania, B. Singh, and P. S. Ahuja, "Harvesting Regimes to Optimize Yield and Quality in Annual and Perennial Stevia rebaudiana under Sub-Temperate Condition," Ind. Crop. Prod., vol. 65, pp. 556-564, 2015.

[48] A. C. Osorio, H. Vega, J. C. Lancheros, H. A. C. Martínez, and J. E. Mosquera, "Horizontal Subsurface Flow Constructed Wetland Removal Efficiency using Cyperus articulates L," Ecol. Eng., vol. 99, pp. 479-485, 2017.

[49] M. Kawai, I. F. Purwanti, N. Nagao, A. Slamet, J. Hermana, and T. Toda, "Seasonal Variation in Chemical Properties and Degradability by Anaerobic Digestion of Landfill Leachate at Benowo in Surabaya, Indonesia," J. Environ. Manage., vol. 110, pp. 267-275, 2012

[50] Sarbidi, "Kajian Regionalisasi Tempat Pemrosesan Akhir (TPA) Sampah menggunakan Metode Analisis SWOT (Studi Kasus TPA Benowo Surabaya)," J. Permukim., vol. 4, no. 1, pp. 10-22.

[51] A. C. Ni'am and I. Warmadewanthi, "Efektifitas Typha Angustifolia dan Eichhornia Crassipes dalam Mengolah Leahate dengan Sistem Constructed Wetland," in Prosiding Seminar Nasional Manajemen Teknologi XVIII, 2013.

[52] A. K. Hidayati, "Pemanfaatan Eceng Gondok (Eichhornia crassipes) untuk Penyisihan Polutan pada Lindi (Studi Kasus: TPA Benowo)," Surabaya, 2011.

[53] K. Morris, "Salinity and Nutrients; Growth and Water use of Aquatic Macrophytes under Controlled and Naturan Conditions," University of Adelaide, 1998. 